Article

\title{
Hindu Students and Their Missionary Teachers: Debating the Relevance of Rebirth in the Colonial Indian Academy
}

\author{
Nalini Bhushan \\ Philosophy Department, Smith College, Dewey House 204, Northampton, MA 01063, USA; \\ nbhushan@smith.edu
}

Received: 25 July 2017; Accepted: 1 September 2017; Published: 19 September 2017

\begin{abstract}
This essay provides a meta-narrative for the philosophical dialogues that took place in colonial India between Scottish missionary philosophers and philosophers of Vedānta on the topic of karma and rebirth. In particular, it offers a reconstruction and analysis of the context and strategy that shaped the content of discussions that were initiated in the pages of the Madras Christian College Magazine in 1909 between Subrahmanya Sastri and AG Hogg and that inspired Radhakrishnan's response in his dissertation entitled "The Ethics of Vedanta and its Metaphysical Suppositions". The broad context is provided by a history of missionary presence in India. The context is further circumscribed by the 'hybrid' character of the position of the missionaries as teachers in departments of philosophy, teaching students of "upper-caste Hindus" in the English medium universities set up by the British in the late nineteenth century. The hermeneutics of form and context is essential to understanding the content of these debates about the ethics and metaphysics of Christianity and Hinduism, where the meaning and significance of the notion of rebirth took center stage. Importantly, these debates in turn shed light on the broader social and political context in which these debates took place.
\end{abstract}

Keywords: Karma; Rebirth; Radhakrishnan; Hogg; Christianity; Hinduism; Vedānta ethics and metaphysics; Scottish missionaries; philosophical and religious debate; colonial India

\section{Introduction}

The Madras Christian College is a liberal arts college in Chennai, Tamilnadu, South India. Founded in 1837 as a missionary endeavor by the Church of Scotland, MCC is one of Asia's oldest extant colleges. ${ }^{1}$ It continues to flourish today as one of Southern India's most prestigious liberal arts colleges (and of which I am a proud alumna). In this essay I focus on a period in the College's intellectual history during colonial rule, and in particular on a Hindu-Christian debate about karma and rebirth that was initiated in 1904 in the pages of the local Madras Christian College Magazine. Each strand of the debate was subsequently developed into a work of global significance: a book by the missionary and philosophy professor AG Hogg, entitled Karma and Redemption (Hogg 1909); and a ground-breaking journal article by his student S. Radhakrishnan, entitled "The Ethics of Vedanta", published in the International Journal of Ethics (Radhakrishnan 1914).

Why look back on this ancient slice of debate in the philosophy of religion? Because it reveals the approach of a particular kind of missionary who taught in a number of the Indian universities during the colonial period, and crucially, because we can see first hand the response of an Indian student who represented a generation of globally aware and cosmopolitan Indian intellectuals who collectively

1 It passed into the administrative hands of the Church of South India in 1947, following Indian independence from British rule. 
crafted a modern Vedānta metaphysics that re-contextualized the role of karma and rebirth not merely for their narrow period in history but for the twenty-first century.

\section{The Philosopher-Missionary: AG Hogg (1875-1954)}

In this section I focus on a special category of missionary in India: the hybrid that I will term the philosopher-missionary. ${ }^{2}$ These missionaries were typically trained in the UK in philosophy and taught philosophy in colonial Indian Universities. Some were attached to missions before they arrived; others were academics who returned to the UK to receive missionary training after a teaching stint in India. I'm interested in this category of missionary for three reasons: first, they were the professors of many of the Indian (Hindu and Muslim) students who would become the distinguished philosophers of their time; second, as philosophers by training who happened also to be missionaries, their primary loyalty was to philosophy, and therefore to the argument in support of their position, even if their ultimate goal was often to show the superiority of Christianity. Third, like the more obviously Indian philosophers who worked in British India, these missionaries were philosophers in India, engaging both with Indian and Western philosophy, and doing so in a self-conscious dialogue between traditions. ${ }^{3}$ The community of missionary philosophers was thus in several respects a reflection of the community of indigenous Indian academic philosophers; perhaps more accurately, they were inextricably entangled members of a single community to which some members might nonetheless deny them admission.

Just as Scotts dominated the British neo-Hegelian scene in the UK, we find that Scots dominated the academic missionary scene in India. ${ }^{4}$ Alfred George Hogg (1875-1954) was trained in philosophy at the University of Edinburgh, Scotland, under the great historian of philosophy Andrew Seth Pringle Pattison (1856-1931). In India Hogg became Professor of Philosophy at Madras Christian College, serving from 1902-1928, appointed after as Principal of the College, in effect serving MCC for almost 30 years. He was also acknowledged as a philosopher with broad credentials, elected president of the nationally renowned Indian Philosophical Congress in $1935 .{ }^{5}$

Hogg's most significant influence on Vedanta philosophy in India derives from his work Karma and Redemption (Hogg 1909) whose subtitle, "An Essay toward the Interpretation of Hinduism and the Re-Statement of Christianity" characterizes the hermeneutic methodology he preferred-that of selective contrast—rather than one of straightforward comparison (or, for that matter, simple dismissal, based on theological doctrine). ${ }^{6}$ Selective contrast, as opposed to comparison, involves the reflective assessment of contrasting ideas and arguments relevant to a particular doctrine rather than merely noting similarities and differences. In a 1904 letter Hogg puts it this way: "I feel that if Christianity is to conquer India the old doctrines must go first and new ones-like the old and yet Indian in color-must take their place" (Reprinted in the introductory essay to the 1970 version of Karma and Redemption by Eric J. Sharpe, p. x). Notably, Hogg's book (1908) was reprinted in 1970. Here is

2 The category of educational missionary was recognized at the time; here I focus on the more specific kind of the educational missionary, namely, the trained philosopher serving in the mission. Other notables (in addition to Hogg) were JS Mackenzie (who wrote the Manual of Ethics, 1892), Alexander Duff (Calcutta, who studied philosophy at the University of Saint Andrews), John Wilson (Orientalist, Wilson College, Bombay) and especially WS Urquhart (philosophy professor at the Scottish Churches College in Calcutta).

3 Indeed, the Indian Missionary Manual (Murdoch 1889) admonishes aspiring missionaries not only to learn vernacular languages and local customs so as to facilitate sermonizing, but also to take an interest in classical languages and the philosophical systems of India in order to immerse themselves in the rich culture into which they are about to enter. The noted missionary Alexander Duff also advocated the study of English by Indians, and of Indian culture and history by missionaries (Duff 1889).

4 For more on the intellectual relationship between Cambridge and India during British occupation, see Bhushan and Garfield, Minds Without Fear: Philosophy in The Indian Renaissance, 2017, Chapter 9, entitled "The Cambridge Connection: Idealism, Modernity and the Circulation of Ideas" (Bhushan and Garfield 2017).

5 His student, S. Radhakrishnan, was elected earlier, as its third President, in 1927.

6 In this connection it is also important to note that it was Scottish Presbyterianism as the Christian religious sub-tradition that fostered Hogg's less doctrinal attitude in the Hindu-Christian debates. 
how Eric Sharpe justified the decision to reprint this work. "This book occupies a place all its own in the history of Christian thought in India; in my judgment it is one of the most powerful and original works of Christian theology ever to have been written by a working missionary" (Duff 1889, Sharpe's introduction, pp. xv-xvi).

Although Hogg, as noted above, was professor of philosophy at Madras Christian College from 1902 to 1928; significantly, he joined the mission only after he was already teaching philosophy in India. This personal history is critical to understanding the attitude and sensibility that Hogg adopted in the debates between Hindu and Christian intellectuals, debates that were to engage him and in which he participated for much of his life. Philosophy mattered to this missionary professor. According to Hogg, "Theoretically, indeed, the claim of philosophy to be the final arbiter of truth is absolute... philosophy is simply the effort to think quite clearly and critically- to let no assumptions pass without question and to be content with nothing less than a completely intelligible account of the whole of experience. By its very definition, therefore, a perfect philosophy would give the fairest and truest possible interpretation of religious experience as well as of all other experience, and if religious belief ventured to interpret religious experience differently from such a perfect philosophy, its interpretation must be wrong..." (Hogg 1909, pp. vi-vii, emphasis added). Hogg, as a Christian missionary, however, simultaneously expressed his absolute commitment to Jesus. "In Jesus the man I meet God himself" (Ibid, p. viii). These twin convictions—one regarding philosophical method, and the other regarding religious faith-are evident in the argument of his book.

The genesis of Hogg's book Karma and Redemption is significant: it first appeared as a series of essays in the Madras Christian College Magazine, and was a response to an essay by Subrahmanya Sastri in the same magazine, entitled "Hindu philosophy", in which Sastri argued that, on the Indian view, there was no mystery regarding the existence of apparently unmerited suffering, in virtue of the Hindu belief in the doctrines of karma and rebirth. All suffering could be accounted for as a consequence of one's actions in past lives. Therefore, Sastri argued, neither justification for such suffering, nor, apparently, social or moral action was required. This therefore constituted the orthodox Hindu challenge to Christianity; the philosopher in Hogg accepted this challenge in the essays he wrote for the magazine.

Hogg argued that the central contrast between "higher" Hinduism (Advaita Vedānta and Christianity (Presbyterian, and focused on the person of Jesus, rather than on Church doctrine) is that between a system that views the universe as essentially juridical and one that views it as essentially moral. This is because, argues Hogg, the Vedānta view is focused on the doctrine of karma as a way of making sense of otherwise unmerited suffering in one's phenomenal life. This metaphysical theory of a cycle of causes and effects ${ }^{7}$, in effect makes punishment (and reward) the primary Hindu concept; even aworse, argues Hogg, morality—actions being viewed as right or wrong—can only be justified as an accidental feature of the phenomenal world. This feature of morality as accidental is reinforced by the fact that for the Hindus, from a transcendental perspective (consistent with dharma), the distinction between the moral and the non-moral disappears. Thus the God of Vedānta is a juridical God, not a moral God. This contingency of the moral, argues Hogg-against Sastri-ought to be problematic for any philosopher who wants to take seriously the ethical perspective and use it to motivate individuals in society to do good.

In proposing a solution, Hogg identifies what he takes to be the central ideas in each tradition and effects a synthesis. He does not advocate for a removal of the doctrine of Karma; instead, he takes seriously the Hindu commitment to karma, suitably reinterpreted, so that it "does express an aspect of God's being" (Hogg 1909, p. 113). While the details of Hogg's synthesis are interesting in their own right, what is significant for the purposes of my essay is that Radhakrishnan, who was then Hogg's

7 And it is metaphysics, not physics, a point to which Hogg returns at the end of his critique (an additional strike against the Vedānta view in the context of modernity). 
student of philosophy at MCC, read the exchange between Sastri and Hogg in the pages of the MCC magazine. Radhakrishnan challenged Hogg's view in his doctoral dissertation entitled "The Ethics of Vedānta and its Metaphysical Suppositions." and responded to both positions, developing his own version of Vedānta idealism. ${ }^{8}$

\section{S. Radhakrishnan (1888-1975): The Student Responds to His Teachers' Challenge ${ }^{9}$}

In "The Ethics of of Vedānta" (1914) Radhakrishnan responds to the challenge posed to Vedānta by Christian missionaries, one not recognized as a challenge by orthodox Hindu scholars. He begins by agreeing that it is fair to ask "how far the Vedānta philosophy satisfies the demands of the moral consciousness" (Radhakrishnan 1914, p. 168). In this way he acknowledges Hogg's challenge to Vedānta. Radhakrishnan responds that indeed, the Vedānta does not contain an explicit set of ethical doctrines, and thus that "it is for the critical student of the Vedānta to bring together the scattered elements and present them as a whole" (ibid).

When approached critically, that is, as a philosopher, Radhakrishnan argues, the ethics of the Vedānta is seen to be not an independently justified set of doctrines but rather entirely dependent upon its metaphysics, which for him is the idealism of "the absolute oneness of all things" (ibid). With respect to individuals in human communities, then, it follows that every human being must be treated as such, that is, "as an end and not a means". And this in turn requires a life of reason. So, instead of taking the moral domain as self-evident, by asking what the features are of the moral life, Radhakrishnan argues that our starting point must be to identify the features of a rational life; this will issue in the moral actions that humans should take with respect to each other. Note here that the motivation of this Vedāntin, justified by Vedānta metaphysics, is, from one perspective, Kantian. But Radhakrishnan immediately juxtaposes this Kantian strand to a strand in The Bhagavad Gita with its emphasis on the control of the senses by reason. In his interpretation of the Gita, "a rational life is not a life of no desire, but a life of regulated desires". This is a feature of the rational life and for Radhakrishnan, constitutes the cornerstone of Vedānta ethics: to think before we act. Vedānta knowledge is "the knowledge that enables us to take a right view of things and our place in the world" (Radhakrishnan 1914, p. 172). And again, "The Vedānta ethics does not ask us to sit with folded hands or, like the mystic, look down on earth or up to heaven, at nothing in particular" (Radhakrishnan 1914, p. 174). The Vedānta focus on knowledge is therefore not an invitation to abstract contemplation.

Radhakrishnan goes on to argue for disinterested-rather than the per impossible unmotivated-action as the necessary consequence of a commitment to Vedānta metaphysics. "The Vedānta law of morality does not ask us to act without motives, but asks us to serve humanity, without any selfish desires or petty interests, without envy or jealousy, regardless of party or personality" (Radhakrishnan 1914, p. 175). Note his introduction of the notion of moral law (dharma) here, but along with it the risk of a problematic association between dharma and the orthodox caste system. Radhakrishnan however immediately offers the following different association and juxtaposition: "The Vedānta criterion of morality may well be expressed in the famous formula made familiar to the philosophic world by the Hegelian school of ethics: 'my station and its duties'" (Radhakrishnan 1914, p. 176). After a discussion regarding the very real situations in which we face a conflict of duties (in a return to the predicament of Arjuna in the Gita), he concludes: "It [The

8 To complete one epicycle in this complex orbit, Radhakrishnan was later to lecture in the United Kingdom and the United States, discussing Indian idealism with British and American philosophers on their respective home turfs.

9 Sarvepalli Radhakrishnan (1888-1975) was educated in India, at Madras, by missionary, Tamil and Sanskrit scholars. Radhakrishnan's early writings were reactions against the view that Vedānta is focused only on the goal of individual self-realization/transformation, without any ethical framework or social philosophy. He argued, demonstrating, contrary to the thinking of both AG Hogg and S Sastri, who were his teachers, that there was in fact an ethics that formed the core of Vedānta. Radhakrishnan's 1908 dissertation was devoted to making the argument in support of this position ); he continued this focus in other work, including a comparative essay entitled "The Ethics of the Bhagavadgitā and Kant" which appeared in the International Journal of Ethics in 1911 and "The Ethics of Vedānta" (same journal as above, 1914). 
Vedānta] holds that there can only be one Absolute in morality as in metaphysics ... The ideal of unselfish service of humanity is the only absolute moral rule which ought never to be broken ... It is the obedience to reason and its ideal of service and sacrifice that is the one supreme law, and all others are subordinate to it" (Radhakrishnan 1914, p. 178).

What just happened here? Far from seeing in Vedanta metaphysics a disconnect from any ethical imperative to care about others, as Christian critics like Hogg had argued, Radhakrishnan instead extracts from the core of Vedānta metaphysics an ethical "categorical imperative" to serve humanity unselfishly! And what about the doctrine of karma and rebirth, the metaphysical commitment that was the original source of Hogg's criticism of the Vedānta? In this connection, Radhakrishnan states: "'Karma' is a hypothesis devised by later Vedānta writers as an explanation of the inequalities of this life and a solution to the problem of future life" (Radhakrishnan 1914, p. 180, emphasis added). He proposes that karma guarantees continuity, but of a restricted kind: "man's past deeds are continued into this life in the form of tendencies or predispositions. But character is not the product of karma" (Radhakrishnan 1914, p. 181). The doctrine of karma, then, does not absolve human beings from ethical duties; rather, it acts as a constraint on our freedom to perform them. This constraint is not absolute; Radhakrishnan likens this constraint to others we face as finite beings (poverty, where we are born, to whom etc.). In this way, the role of karma as it operates in the actual world is not unlike the role of any other material constraint that operates on us even as we "fight for" standing firm and doing the right thing.

Finally, Radhakrishnan addresses the criticism that Vedānta cannot justify treating persons as individual selves, with their own autonomy and dignity, a core requisite of morality. If we are all slivers of Krishna or aspects of divine consciousness, so the argument goes, then others are simply an aspect of ourselves, and our treatment of them is justified on self-centered rather than on moral grounds. On this point, however, Radhakrishnan doubles down on the Vedānta position rather than retreat from it: "The Vedānta philosophy teaches us that our lives are not ours. They belong to humanity, which ought not to be deprived of its possessions. Render unto humanity what belongs to humanity" (Radhakrishnan 1914, p. 182). Rather than the missionary perspective of Vedānta metaphysics that would view others as a version of me (leading to a self-centered ethics), Radhakrishnan invites us to consider the reverse: a modern Hindu perspective on Vedānta metaphysics according to which me and my life are inconsequential absent the rest of humanity (leading to an other-centered ethics). ${ }^{10}$

\section{Conclusions: Coming Back Full Circle to MCC and to the Case of the Hindu Student and His Missionary Teacher}

My goal in this essay has been to use one example to showcase a practice of sustained critical discussion between ethnically British and ethnically Indian philosophers on metaphysical and ethical issues raised by both traditions. The circulation of ideas ${ }^{11}$ between these communities is more representative of the history of Indian philosophy during this period than is a description in terms of hegemonic imposition of a Western canon.

Noteworthy as well is the reformulation and transformation of each of their ideas. Hogg brings nuance to the respective notions of Hindu karma and Christian redemption. His careful consideration of the doctrine of karma and of Vedāntin metaphysics leads him to write a text that, to use Sharpe's terminology, "is a work, not of Christian apologetics for India merely, but of universal Christian theology. It should have never been allowed to drift into oblivion" (Hogg 1909, p. xviii).

10 Radhakrishnan subsequently put to one side his preoccupation with the challenge posed by his missionary teacher and concerned himself in his other writings with the challenge posed to all religions by modernity, and in particular by the advent of science.

11 Also represented in a more explicitly theological register in Ram Mohan Roy's engagement with Christianity. 
Radhakrishnan, for his part, continues to value karma, but justifies the equal ethical treatment to all human beings based on his metaphysical commitment to non-duality or essential "oneness". ${ }^{12}$ The metaphysical truth of karma is only justifiably activated as an explanation (not a reason) for our suffering from the transcendental standpoint. In effect, Karma itself seems to be contextualized to a view that explains (seemingly) unmerited suffering but does not justify ignoring suffering and other forms of unequal treatment of other human beings in a particular life time. ${ }^{13}$

When we look back at the nature of this particular exchange, and others like it during the colonial period, we find that these intellectuals, while they approached thorny issues from their respective religious perspectives, nevertheless took each other as serious intellectual interlocuters. They also used ideas that were circulating globally in their time in the service of their particular arguments. As a result, Hindu and Christian perspectives in twentieth century modernity were better understood, respected and acquired more nuance. This respect for person and argument, however alien they may at first appear, and, respect for the notion of a world of ideas accessible and available to anybody, is a lesson we can learn as intellectuals and inheritors of their legacy in the twenty-first century.

It is equally the legacy of the very best teachers that their very best students outperform them. While Hogg fell into relative obscurity, Hogg's student, Radhakrishnan, became a professor of philosophy, serving at many of the top universities in India ${ }^{14}$, acquiring an international reputation, invited in 1926 to Oxford to give the Upton Lectures, and in 1929 the prestigious Hibbert Lectures at the University of Manchester and University College, London. In 1936, Oxford University appointed him to the H.N. Spalding Chair of Eastern Religions and Ethics. ${ }^{15}$ And, in 1962, he became the second President of an independent India.

Acknowledgments: This paper was presented at the AAR, under the auspices of the Dharma Academy of North America (DANAM), in San Antonio, Texas, 18 November 2016, as part of a panel entitled Interrogating Rebirth: Hindu-Christian Debates and their Contemporary Relevance. Many thanks to my co-panelists Jonathan Edelmann, Gerald Larson, Brad Malkovsky, Jeffery Long and Francis Clooney for a terrific discussion.

Conflicts of Interest: The author declares no conflict of interest.

\section{References}

Bhushan, Nalini, and Jay L. Garfield. 2017. Minds without Fear: Philosophy in the Indian Renaissance. New York: Oxford University Press.

Duff, Alexander. 1889. India and Indian Missions including Sketches of the Gigantic System of the Hindus. Edinburgh: John Johnstone.

Hogg, Alfred George. 1909. Karma and Redemption: An Essay toward the Interpretation of Hinduism and the Re-Statement of Christianity. Madras: Christian Literature Society.

Kalapati, Joshua. 2002. Dr. S. Radhakrishnan and Christianity: An Introduction to Hindu-Christian Apologetics. Delhi: ISPCK.

12 Since there are two operational standpoints (Radhakrishnan uses the term "platform"), the metaphysical and the empirical, at the mundane level individuals do matter as distinct persons and are treated as such even as from a higher standpoint one recognizes that these persons are non-different. While the theory of non-difference is also a view from the transcendental standpoint, it does get activated at the empirical level. Radhakrishnan himself calls the doctrine of karma an explanatory theory while non-difference or the essential one-ness of things refers also to a state of being to be experientially realized. Vedānta ethics is dependent on this metaphysical truth and not justifiable independent of it. Thus neo-Kantian and Hegelian ethics is only justifiable in light of this higher purpose.

13 For more details about Hogg's influence on the thinking of Radhakrishnan, see (Kalapati 2002).

14 Including the Universities of Mysore and Calcutta, where he was appointed the King George V Chair of Philosophy in 1921.

15 A chair later held by Bimal K Matilal. 
Murdoch, John. 1889. Indian Missionary Manual, 3rd ed. London: James Nisbet and Co.

Radhakrishnan, Sarvepalli. 1914. The Ethics of Vedānta. International Journal of Ethics 24: 168-83. Available online: http:/ / www.jstor.org/stable/2376505 (accessed 16 May 2016). 